\title{
A Longitudinal Analysis of Language Ability based on Language-use in Multicultural Families: Verifying the Mediating Effect of Bicultural Acceptance Attitude and Ego-resilience
}

\author{
Dongsun Yim, Sunyoung Kim, Sungjin Kim, Soeun Kim, Yoonhee Yang \\ Department of Communication Disorders, Ewha Womans University, Seoul, Korea
}

Correspondence: Dongsun Yim, PhD Department of Communication Disorders Ewha Womans University, 52 Ewhayeodae-gil, Seodaemun-gu, Seoul 03760, Korea

Tel: $+82-2-3277-6720$

Fax: +82-2-3277-2122

E-mail: sunyim@ewha.ac.kr

Received: October 16, 2020

Revised: November 12, 2020

Accepted: November 19, 2020

This work was supported by the Ministry of Education of the Republic of Korea and the National Research Foundation of Korea (NO. NRF2018S1A3A2075274).

\begin{abstract}
Objectives: The purpose of this study was to compare language skills of multicultural adolescents between families where their foreign mother speaks only Korean (K-only) and families where the mother speaks both Korean and mother language in communication(KM). This study also aims to investigate mediating effects of national identity, bicultural acceptance attitude, acceptance of multiculturalism, and ego-resilience of two groups on the relationship between language abilities of children in the 5 th grade in elementary school and 2nd grade in middle school. Methods: A one-way ANOVA and a structural equation analysis were used to analyze the data. A total of 315 participants subject's data from Multicultural Adolescents Panel Study organized by National Youth Policy Institute was used for the data analysis. Results: There was no statistically significant difference between two groups in Korean skills, with the exception of the writing skill in the 1st grade in middle school. However, mother language ability was significantly higher in the K-M group every year. Additionally, the Korean skills of the K-only group was mediated by ego-resilience. Mother language ability of the K-M group was mediated by bicultural acceptance attitude. Lastly in the K-M group, ego-resilience was mediated by Korean ability in the 5th grade of elementary school and Korean and mother language ability in the 2nd grade in middle school. Conclusion: Foreign mothers speaking their mother tongue is not an interfering factor in Korean language development for multicultural adolescents. The bilingual environment is positive for children's language development, and ego-resilience can serve as a protective factor for multicultural children's language development.
\end{abstract}

Keywords: MAPS, National identity, Bicultural acceptance attitude, Acceptance of multiculturalism, Ego-resilience, Language ability
한국 사회에서 다문화 가정 수는 꾸준히 증가하고 있다. 다문화 가정 가구 수는 2015년 290,000 가구에서 2018년 350,000가구로 늘어났고(Statistics Korea, 2018), 다문화 자녀의 수 또한 2012년 조 사 이후부터 매년 증가 추세를 보이고 있다. 실제로 초등학교부터 고등학교까지 재학 중인 다문화 자녀의 수는 2019년 기준으로 총 137,225 명으로 전년 대비 12.3\% 증가하였다(Korean Educational Statistics Service, 2019). 2018년 다문화 가정 자녀의 연령 분포를 분석한 결과 학령 전기에 해당하는 6세 미만 자녀의 비율이 $39.0 \%$,
초등 학령기에 해당하는 만 6-11세 자녀의 비율이 $38.2 \%$, 중학교 학령기인 12-14세 자녀의 비율이 $8.6 \%$, 고등학교 학령기에 해당하 는 15-17세 비율은 5.8\%를 차지한다. 이러한 추세로 볼 때 향후 자 녀의 평균 연령은 점차 증가할 것으로 보인다(Ministry of Gender Equality \& Family, 2018). 이처럼 다문화 가정과 청소년이 꾸준히 증가하고 있는 상황에서 이들이 우리 사회에 적응하여 소외되지 않고자리 잡을수 있도록 사회적인 관심과 지원이 필요하다.

특히 초등학교에서 중학교로 넘어가는 시기는 아동에게 커다란 
변화의 시기이므로 이 시기의 아동에 대한 관심과 연구가 필요하 다. 이 시기에 청소년들은 발달적으로 큰 변화를 경험할 뿐 아니라 환경적으로도 많은 변화에 직면한다. 예를 들어, 초등학교와 비교 하여 한 학급당 학생 수가 늘어나며, 담임교사가 모든 과목을 전담 하던 체계에서 과목마다 교사가 바뀌는 체계로 변화하는데, 아이 들은 이러한 변화에 새롭게 적응해야 한다(Park \& Lee, 2017; Marshall \& Neuman, 2011). 또한 자율성에 대한 욕구는 높아지나 대체 로 교사의 통제는 더 심해져 많은 아이들이 혼란을 겪게 된다(Park \& Lee, 2017). 이러한 보편적인 어려움 위에 다문화 가정 청소년들 은 다문화적 배경이 야기할 수 있는 또 다른 어려움이 겹쳐 이중적 어려움(double disadvantage)을 겪게 될 가능성이 높다(Park \& Lee, 2017). 따라서 다문화 가정 자녀가 전환기에 겪게 될 적응의 어려움 을 이해하고 적응을 도울 수 있는 연구가 필요한 실정이다. 언어적 문제는 문화적 차이와 더불어 다문화 가정 자녀의 학교 부적응의 주된 원인임이 밝혀졌다(Cho, 2006). 다문화 가정 자녀의 적응과 언어 능력이 깊은 상관이 있다는 이러한 연구 결과는 다문화 가정 자녀의 언어 능력을 향상시켜주는 것이 중요함을 시사한다. 2018년 다문화 가정 내 평소 언어 사용 실태를 조사한 결과, 외국인 부모의 모국어 사용이 제한되어 있으며 자녀에게 외국인 부모의 모국어를 교육하지 않는 것으로 나타났다. 평소 가정에서 외국인 부모의 모 국어를 사용하는 것에 대해 배우자나 가족이 격려해준다는 긍정 적인 응답은 $35.3 \%$ 인 반면, 부정적인 응답이 $41.1 \%$ 로 더 많았다. 2015년도 조사결과와 비교하여 긍정적인 응답이 오히려 소폭 줄어 들고 있으며, 가정 생활에서 모국어 사용을 격려 받는 정도를 시계 열적으로 비교해 보면, 2012년 이후 지속적으로 척도 점수가 낮아 지고 있다. 즉, 외국인 부모의 모국어 사용을 배우자나 가족들이 긍 정적으로 허용하고 있다는 인식이 오히려 감소하는 것이다. 한국 사회에서 다문화 가족을 지원하고 문화다양성을 중시하는 정책 및 연구들이 전반적으로 확산되어 온 흐름과는 달리, 실제 한국에 거 주하는 외국인 부모는 일상적인 가정 생활에서 모국어 사용을 격 려 받지 못하는 현실이 지속되는 것으로 볼 수 있다. 출신 국적에 따 라서는 미국·유럽.대양주 출신은 가족들이 자신의 모국어 사용에 대해 허용적인 것으로 인식한 반면, 중국(한국계), 대만 - 홍콩, 캄보 디아 출신은 모국어 사용을 격려 받는다는 인식이 낮은 편으로 나 타났다. 또한 가정에서 자녀에게 어머니의 모국어를 가르친다는 응 답도 15 년도에 $3.07 \%$ 에서 18 년도 $2.98 \%$ 로 다소 감소하였다. 다문 화 가정 자녀의 $52.3 \%$ 는 외국 출신 부모의 모국어를 사용하도록 격 려하지 않는 환경에 놓여있으며, 실제 외국 출신 부모의 모국어를 배우는 비율은 $25.1 \%$ 에 불과한 실정이다. 외국인 어머니가 모국어 를 사용하는 데에 부정적 인식이 가정 내 자녀에게 어머니의 모국
어를 교육하지 않는 것으로 이어진 것으로 볼 수 있다(Ministry of Gender Equality \& Family, 2018). 이러한 실태는 외국인 부모의 미 숙한 한국어 능력이 자녀에게 적절한 언어 자극을 주지 못하여 궁 극적으로 자녀의 언어 실력에 부정적 영향을 미치며 이러한 어려움 은 초등학교 고학년에 접어들며 학습에 요구되는 한국어 수준이 외국인 부모의 한국어 능력 수준을 뛰어 넘게 될 때 두드러질 수 있 다(Oh, 2005; Oh, Kim, \& Kim, 2009). 하지만 많은 선행연구에 따 르면, 가정에서의 이중 언어 사용에 의한 자녀의 언어발달 지연효 과는 유의하지 않았고, 중학생의 경우에는 오히려 이중 언어를 사 용하는 집단이 한국어만 사용하는 집단이나 외국인 어머니의 모 국어만 사용하는 집단보다 국어 과목의 모든 하위영역의 평균 점 수가 통계적으로 유의하게 높았다(Park \& Kim, 2016). 더불어 다문 화 가정 내에서 자녀가 자연스럽게 이중 언어를 습득한다는 것은 언어 능력에 긍정적 영향을 미칠 뿐 아니라, 그 민족에 대한 이해로 이어진다. 따라서 자연스럽게 타민족과의 상호교류 확대 및 적응력 을 높이는데 일조한다(Nho \& Hong, 2006). 이와 같은 연구결과는 이중 언어 환경이 다문화 가정 자녀들의 적응에 위험요소라는 앞 선 연구와는 다른 결과로 어머니의 모국어와 제 2 언어인 한국어를 함께 사용하는 것이 자녀의 언어 능력 및 적응도에 긍정적인 영향 을 미칠 수 있음을 시사한다(Park, Lee, \& Park, 2014). 그럼에도 불 구하고 기존의 연구들은 다문화 청소년의 부정적인 발달에 영향을 미치는 요인에 초점을 맞추어 왔다(Kim, Jung, Shim, \& Lee, 2017). 그러나 다문화 청소년이 급증하고 있는 현 상황에서 이들이 사회 의 구성원으로서 역량을 발휘할 수 있도록 문제점보다는 보호 요 인에 집중하는 것이 필요하다. 따라서 주어진 환경 속에서 부정적 요인을 완충하는 매개변수가 무엇인지 규명하는 노력이 중요하다 (Lee \& Chang, 2019).

따라서 본 연구에서는 두 언어 능력 변수 사이에 어떠한 개인 내 적인 요소가 매개변수로서 작용할 수 있는지 알아보고자 하였고 자녀의 개인 내적인 요소인 '정체성'에 주목하였다. 정체성은 사회 적 태도와 성향을 확립하는 사회적 준비 시기인 청소년기에 형성된 다(Erikson, 1959, 1968). 이때 정체성 확립이 제대로 이루어지지 않 으면 역할 갈등 및 부작용을 경험할 수 있다(Park, 2002). 선행연구 에 따르면 다문화 청소년의 언어와 문화, 그리고 가치관의 차이로 인한 정체성의 혼란이 집단 따돌림이나 사회적 편견으로 인해 더욱 가중되어 낮은 자존감을 보이고 있다(Jeong, Yoo, \& Lee, 2007). 정 체성을 형성하는 데는 자기인식을 필요로 하는데(Kim-Ju \& Liem, 2003) 외모적으로나 문화적으로 다른 다문화 가정 자녀들은 배타 적일 수 있는 환경 속에서 자신을 수용적인 태도로 인식하고 받아 들이는데 상대적으로 어려움이 있는 것으로 보인다. 따라서 다문 
화 자녀의 '청소년 시기'의 '정체성'에 대해 살펴보는 것은 의의가 있 으며(Jeong et al., 2007) 이러한 정체성은 스스로에 대한 인식뿐 아 니라 한국어와 어머니의 모국어에 대한 인식과 능력으로까지 그 영 향이 이어질 수 있다. 다양한 문화에 노출된다는 것을 고려하여 다 문화 청소년의 정체성의 하위요소로 국가정체성, 이중문화수용태 도, 다문화수용성, 그리고 자아탄력성을 고려하였다.

첫 번째 매개변수인 '국가정체성'이란, 사회정체성의 한 형태로 특정 국가 또는 국민에 대해 사람들이 갖는 신념과 감정을 의미하 며(Chung \& Lee, 2011; Wiggins, Wiggins, \& Zaden, 1994). 개인의 국가정체성이 어떠한가에 따라 국가에 대한 자긍심, 애착, 소속감, 충성심, 우월감 또는 열등감과 같은 감정의 유형 및 정도가 달라진 다. 이러한 국가정체성은 '언어'와 밀접한 관계가 있다(Kim, 2011). 언어는 국가공동체의 공통 특징이며 이는 공동체의 정체성의 중요 한 한 요인이 된다(Crystal, 2010; Kim, 2011). 국가정체성은 함께 공 유하는 상징을 기반으로 형성되는데(Bloom, 1990), 이때 '언어'는 국가의 중요한 상징 중 하나로 작용하기 때문에 국가정체성과 밀접 한 관계를 맺는다고 할 수 있다. 언어가 국가정체성을 형성하는 데 중심적인 역할을 하는 사례로 먼저, 한 국가에 다양한 민족과 부족 이 서로 다른 언어를 사용하며 공존하는 아프리카 지역의 국가들 을 볼 수 있다. 식민통치 당시 남아공에 이주하여 정착한 백인들은 하나의 국민이 아니었으며 본래 쓰던 언어 또한 달랐으나 아프리칸 스어(Afrikaans)라는 하나의 매개체를 중심으로 국가정체성을 형 성하였다(Ormans, 2008). 심층면접방법을 통해 한-일 다문화 자녀 의 국가정체성을 분석한 연구에서도 연구참여자 8 명 중 7 명은 모 두 자신이 성장한 국가의 정체성을 내면화하였는데 이때 성장 국가 의 언어를 사용한다는 점이 가장 크게 작용하였음을 밝혔다(Kim, 2018). 이처럼 어떤 언어를 주로 사용하는가는 다문화 가정 구성원 의 국가정체성에 영향을 미친다. 반면 사용 언어 외에도 외국인 어 머니의 출신 국가 및 지역이 자녀의 국가정체성 형성과 관련이 있다 (Geum, Kwon, \& Lee, 2004; Lee \& Kang, 2011). 베트남 및 필리핀 과 같은 비아시아권과 일본, 중국, 조선족과 같은 동아시아권 출신 의 결혼이주여성의 자녀가 인지하는 한국에 대한 국가정체성을 비 교한 결과 어머니가 동아시아계인 청소년의 $60 \%$ 가 자신을 한국인 이라고 생각한 반면, 비아시아계인 경우 $21.4 \%$ 만이 한국인으로 생 각하는 차이를 보였다(Geum et al., 2004). 동아시아권 내에서도 일 본인 어머니의 자녀에 비해 조선족 어머니의 자녀의 경우 한국인이 라고 느끼는 국가정체성이 일본인 어머니 자녀의 경우보다 유의미 하게 높았는데 이는 어머니가 일본인인 다문화 청소년은 일본인이 라는 자부심과 일본 문화에 대한 주변의 긍정적 인식이 한국 문화 에 대한 정체감보다 일본인으로서의 강한 정체감을 형성하게 하였
음을 보여준다(Lee \& Kang, 2011). 이처럼 외국인 어머니와 한국인 아버지 밑에서 자란 다문화 가정 자녀의 국가정체성 형성에 영향 을 미치는 요인이 무엇인지에 대한 의견은 다양하다. 또한 언어가 국가정체성 형성에 미치는 영향에 대한 선행연구에 비해 반대로 국 가정체성이 언어에 미치는 영향에 대한 연구는 미흡한 설정이다. 하지만, 정체성 형성에 있어 혼란이 가중될 수 있는 환경에 처한 다 문화 가정 자녀들의 국가정체성이 이후 한국어 또는 외국인 어머 니 국가의 언어 능력에 영향을 미칠 것으로 가정하였고 다문화 가 정 내의 언어 사용 양상에 따라 자녀의 언어 능력에 미치는 국가정 체성의 매개효과가 유의한 차이가 있는지 분석하는 것이 의미가 있을 것으로 판단된다.

두 번째 매개변수는 '이중문화수용태도'이다. 다문화 가정 청소 년은 부모가 모두 한국인인 청소년과는 다르게 가족 내에서 '이중 문화’라는 독특한 환경을 경험하며 성장하기 때문에 가정의 내부 적인 환경이 다문화 가정 청소년의 발달에 어떠한 영향을 미치는지 에 대해 알아보는 것은 중요하다. 다문화 가정 자녀의 이중문화수 용태도는 한국에서 주류 문화인 한국 문화와 비주류 문화인 외국 인 부모 나라의 문화에 대한 수용태도를 의미하는 것으로 높은 이 중문화수용태도가 또래 관계, 자아탄력성, 학교 적응에 긍정적인 영향을 미친다는 선행연구 결과가 있다(Kim \& Yang, 2012; Nho \& Hong, 2006). 이렇듯 '이중문화수용태도'는 다문화 가정의 청소년 에게 중요한 영향을 미치지만 아직 이중문화수용태도와 언어 간 관계를 살펴본 연구는 부족하다.

세 번째 매개변수는 '다문화수용성'으로, 문화간 유능성(Bennett \& Bennett, 2004), 다문화 유능성 혹은 역량(Sercu, 2004) 등 다양한 용어로 사용되어 왔으나 국내에서는 이러한 능력을 다문화 수용성으로 표현하는 경향이 있다(Kim \& Lee, 2015; Kim \& Jeong, 2010; Yoon \& Song, 2011). 다문화수용성은 다양한 문화의 가치를 인정하고, 공존을 수용하며, 타문화에 대해 편견 없이 상대 의 입장과 생각, 행동에 공감하고 친밀한 관계를 형성할 수 있는 능 력으로 정의될 수 있다(Kim \& Jeong, 2010). 외국인의 유학, 취업 및 국제결혼 등의 증가로 우리 사회에는 과거에 비해 훨씬 더 다양한 문화가 유입되고 있어 다문화에 대한 이해와 수용이 더욱 강조되 고 있다. 따라서 다문화에 대한 아동.청소년의 인식 및 주변 환경 에 대한 이해를 조사하는 것은 반드시 필요하다고 할 수 있지만, 다 문화수용성과 자아존중감의 관계를 살펴본 연구나 언어와의 관계 를 살펴본 연구는 많지 않다.

마지막 네 번째 매개변수는 ‘자아탄력성'이다. 자아탄력성이란 어려운 상황에서 융통성을 발휘하여 적응하게 하는 개인의 능력을 의미한다(Block \& Block, 1980). 즉, 자아탄력성은 나에게 주어진 
부정적인 환경 속에 갇히지 않고 용수철처럼 탄력을 받고 튀어 올 라 환경을 극복할 수 있게 하는 내면의 힘이라고 할 수 있다. 자아탄 력성은 '다문화 청소년이 환경적 위험 요인에 노출되었을 때 위험 요인을 받아들이는 방식'과 ‘학교 및 사회적응력'에 중요한 변인으 로 우리나라의 문화 적응에 있어 어려운 상황을 겪는 다문화 가정 자녀들에게 특히 자아탄력성이 매우 중요하다(Kim, CUI, \& Nho, 2019; Lim, 2019). 다문화 가정 자녀의 자아탄력성은 언어 능력과 밀접한 관계를 갖는데 외국인 부모 나라의 언어 능력은 다문화 자 녀의 자아탄력성 형성에 중요한 영향을 미치는 요인이다(Kim \& Yang, 2012). 다문화 가정 청소년의 이중 언어 능력 자체가 학교생 활에 영향을 미치기도 하지만 자아탄력성이 그 사이를 매개하여 학교생활에 긍정적 영향을 미친다(Go \& Kim, 2018). 또한 다문화 청소년패널(Multicultural Adolescents Panel Study, MAPS) 자료를 이용한 종단연구에 따르면, 외국인 어머니 모국어와 한국어를 모 두 고려한 다문화 가정 자녀의 언어 능력은 초기 자아탄력성에 정 적인 영향을 미치는 것으로 나타났다(Kim et al., 2017). 그러나 다 문화 가정 자녀의 언어 능력은 자아탄력성에 영향을 미치는 반면 자아탄력성이 언어 능력에 긍정적인 영향을 미치는가에 대한 연구 역시 거의 이루어지지 않았다.

이러한 선행연구를 토대로 본 연구에서는 청소년기에 해당하는 초등학교에서 중학교로의 전환기에 있는 다문화 가정 자녀의 '한 국어' 및 '어머니의 모국어' 능력을 살펴보고자 한다. 특히 가정 내 외국인 어머니와 자녀 간 의사소통 시 한국어만 사용할 때와 한국 어와 어머니의 모국어를 혼용하여 사용할 때 자녀의 언어 능력에 유의한 차이를 보이는지 확인하기 위하여 연구 집단을 '한국어만 사용하는 집단'과 ‘한국어와 어머니의 모국어를 혼용하는 집단'으 로 나누었다. 또한 집단별 자녀의 모국어 및 한국어 언어 능력이 국 가정체성, 이중문화수용태도, 그리고 자아탄력성을 매개로 어떻게 변화하였는지 종단적으로 살펴보고자 한다. 이를 위해 한국청소년 정책연구원에서 2011년도부터 매년 반복적으로 조사하여 수집한 다문화청소년패널 데이터를 활용하여 다음과 같은 연구문제를 살 펴보고자하였다.

1. 부모-자녀 간 의사소통 시 한국어만 사용하는 집단과 한국어 와 어머니의 모국어를 혼용하여 사용하는 집단 간 자녀의 언어 능 력(한국어, 어머니의 모국어)에 유의한 차이가 있는가?

2. 부모-자녀 간 의사소통 시 한국어만 사용하는 집단과 한국어 와 어머니의 모국어를 혼용하여 사용하는 집단 간 자녀의 자아탄 력성, 국가정체성, 이중문화수용태도, 다문화수용성에 유의한 차 이가 있는가?

3. 부모-자녀 간 의사소통 시 한국어만 사용하는 집단과 한국어
와 어머니의 모국어를 혼용하여 사용하는 집단 각각에서 자녀의 초등학교 5 학년 언어 능력(한국어, 어머니의 모국어)은 매개요인 (자아탄력성, 국가정체성, 이중문화수용태도, 다문화수용성)을 통 해 중학교 2 학년의 언어 능력(한국어, 어머니의 모국어)을 설명하 는가?

\section{연구방법}

\section{연구대상}

본 연구에서는 한국청소년정책연구원의 다문화청소년패널조사 (MAPS)의 데이터를 활용하였다. 본 데이터는 2011년을 기준으로 초등학교 4학년에 재학 중인 다문화 청소년과 그들의 어머니를 대 상으로 2019년까지 매년 진행된 종단 조사 지표이다. 본 연구에서 는 시기적으로 초등학교에서 중학교로의 전환기에 해당하는 2012 년부터 2015년까지의 2-5차년도 자료를 사용하였다. 2014년에 조 사된 초등학교 4 학년 때의 1 차년도 자료에는 본 연구의 주요 지표 중 하나인 ‘다문화수용성'이 수집되지 않아 초등학교 5학년에 해 당하는 2 차년도부터 분석하였다. 즉, 다문화청소년패널 원 자료 중 주요변수인 자녀의 한국어와 모국어 언어 실력, 국가정체성, 이중 문화수용태도, 다문화수용성, 자아탄력성에 대한 정보가 모두 제 공되는 2-5차년도 자료를 사용하였다.

본 연구의 분석 표본은 '부모와 자녀 간 의사소통 시 사용하는 언어'를 기준으로 선별하였다. 한국어만 사용하는 집단의 경우, 부 모와 자녀가 모두 ‘한국어'를 사용하여 의사소통한다고 응답한 경 우를 포함시켰다. 한국어와 어머니의 모국어를 혼용하여 사용하는 집단의 경우, 부모와 자녀가 모두 한국어와 어머니의 모국어를 혼 용하는 것으로 응답한 경우를 포함시켰다. 이 때 어머니와 자녀의 응답이 일치하지 않거나, 각 개인의 응답이 2-5차년도 내에서 달라 진 경우를 제외하였다. 이 같은 과정을 통해 최종적으로 한국어 사 용 집단은 203명, 한국어와 모국어를 혼용하는 집단에는 112 명, 총 315 명의 다문화 청소년을 대상으로 분석을 수행하였다. MAPS에 서 구축한 표본은 약 1,625 명으로 본 연구대상은 원자료의 $19.4 \%$ 에 해당한다.

본 연구에 포함된 학생들의 어머니들은 모두 외국 출신이었는데 이들의 출신 국가를 살펴보면 부모와 자녀 간 의사소통 시 오로지 한국어만 사용하는 집단(only-Korean speaking group, K-only)에 서는 중국(조선족)이 61명(30.0\%)로 가장 많았으며, 그 다음 일본 49명(24.1\%), 필리핀 38명(18.7\%), 중국(한족, 기타민족)이 27명 (13.3\%), 베트남 10 명(4.9\%), 태국 4명(2.0\%) 순이었다. 한국어와 어 머니의 모국어를 혼합하여 사용하는 집단(both Korean and Moth- 
Table 1. Mother's nationality

\begin{tabular}{lcc}
\hline Mother's nationality & K only (N=203) & K-M (N=112) \\
\hline China (Han Chinese, other ethnic groups) & $27(13.3 \%)$ & $10(8.9 \%)$ \\
China (Chosun) & $61(30.0 \%)$ & $14(12.5 \%)$ \\
Vietnam & $10(4.9 \%)$ & $0(.0 \%)$ \\
Philippines & $38(18.7 \%)$ & $19(17.0 \%)$ \\
Japan & $49(24.1 \%)$ & $59(52.7 \%)$ \\
Thailand & $4(2.0 \%)$ & $5(4.5 \%)$ \\
Etc. & $14(6.9 \%)$ & $5(4.5 \%)$
\end{tabular}

Values are presented as frequency $(\%)$.

K-only= only Korean speaking group; K-M = both Korean and Mother tongue speaking group.

er's language speaking group, K-M)에서는 일본 59명(52.7\%), 필리 핀 19명(17.0\%), 중국(조선족) 14명(12.5\%), 중국(한족, 기타민족) 10 명(8.9\%), 태국 5명(4.5\%) 순이었다. 이에 대한 세부 정보는 Table 1에 제시하였다.

\section{연구변인}

MAPS의 조사 문항은 관련 학문 분야에서 널리 사용되어 신뢰 도와 타당도가 확보된 척도를 사용하는 것을 기본으로 하였다. 이 과정에서 전문가 자문회의를 진행하였으며, 예비조사를 실시하여 조사 대상의 연령을 고려하여 문항의 난이도를 조절하였고, 요인 분석을 통해 요인 부하량이 0.5 인 문항은 삭제하여 이해하기 쉽고 간략한 척도로 구성되었다. 또한 주관적인 자가평정척도 임에도 빅 데이터로 그 결과에 신뢰도가 있다고 할 수 있다.

\section{자녀의 언어 실력}

다문화청소년패널 연구에서 조사된 자신의 한국어 실력과 외국 출신 어머니의 모국어 실력 척도 문항을 활용하였다. 본 척도는 자 기평정척도로, 자녀 스스로가 주관적으로 평가하였다. 한국어 실 력 척도는 미국에서 고안된 CILS (Children of Immigrants Longitudinal Study)의 문항을 수정하여 활용하였다. 구체적인 문항과 척도는 다음과 같다. '학생 한국어(말하기) 능력', '학생 한국어(쓰 기) 능력', '학생 한국어(읽기) 능력', '학생 한국어(듣기) 능력'에 대 하여 4 점 척도 $(1$ 점 $=$ 전혀 못한다, 2점 $=$ 못하는 편이다, 3 점 $=$ 잘하 는 편이다, 4 점 $=$ 매우 잘한다)로 평정하도록 하였다. 어머니의 모국 어 실력은 같은 방식으로 네 개의 영역에서 동일하게 4 점 평정 척도 로 측정되었다. 한국어 실력의 Cronbach's $\alpha$ 값은 2차년도(초5) $.943,3$ 차년도(초6) $.967,4$ 차년도(중1) .934, 5차년도(중2) .962로 나 타났다. 어머니의 모국어 실력의 Cronbach's $\alpha$ 값은 2차년도(초5) $.965,3$ 차년도(초6) $.957,4$ 차년도(중1) .953, 5차년도(중2) .952로 나 타났다.

\section{국가정체성}

다문화청소년패널 연구에서 조사된 국가정체성 척도 문항을 활 용하였다. 국가정체성 척도는 Seong (2001)에서 발췌 및 수정하여 활용하였다. 총 4 문항이며 구체적인 측정 문항은 다음과 같다. (1) 누군가 한국을 칭찬하면 내가 칭찬받는 것 같다, (2) 나는 다른 나 라 사람들이 한국에 관해서 어떤 생각을 갖는지에 관심이 많다, (3) 한국의 성공이 곧 나의 성공이다, (4) 누군가 한국에 대해 나쁘게 이야기하면 나에게 욕하는 것 같아서 기분이 상한다. 응답은 4점으 로(1점=전혀 그렇지 않다, 2점=그렇지 않은 편이다, 3점=그런 편 이다, 4 점 $=$ 매우 그렇다) 평정하도록 하였다. 점수가 높을수록 국가 정체성이 높음을 의미한다. 국가정체성의 Cronbach's $\alpha$ 값은 2차년 도(초5) .809, 3차년도(초6) .861, 4차년도(중1) .852, 5차년도(중2) .898로 나타났다.

\section{이중문화수용태도}

다문화청소년패널 연구에서 조사된 이중문화수용태도 척도 문 항을 활용하였다. 본 연구에서는 Nho와 Hong (2006)에서 발췌 및 수정하여 사용한 이중문화수용태도 8 문항으로 점수를 산출하였 다. 구체적인 문항은 다음과 같다. 이중문화수용태도의 경우 (1) 나 는 외국인 부모님이 외국인이라는 것이 자랑스럽다(1-3차)/나는 부 모님이 외국인이라는 것이 자랑스럽다(4-6차), (2) 나는 한국에 살 고 있다는 것이 자랑스럽다, (3) 나는 앞으로 계속 한국에 살고 싶 다, (4) 나는 앞으로 외국인 부모님 나라에 가서 살고 싶다, (5) 나는 한국의 대학이나 회사에 다니고 싶다, (6) 나는 외국인 부모님 나라 로 가서 대학이나 회사에 다니고 싶다, (7) 나는 외국인 부모님 나라 의 문화를 배우는 것이 중요하다, (8) 한국문화를 배우는 것은 내게 중요하다, 이다. 응답은 4 점 척도로 (1점=전혀 그렇지 않다, 2 점 =그 렇지 않은 편이다, 3점=그런 편이다, 4 점 =매우 그렇다) 평정하였 다. 이중문화수용태도의 Cronbach's $\alpha$ 값은 2차년도(초5) .690, 3차 년도(초6) .758, 4차년도(중1).769, 5차년도(중2) .721로 나타났다.

\section{다문화수용성}

다문화청소년패널 연구에서 조사된 다문화수용성 척도 문항을 활용하였다. Yang과 Jeong (2008)을 수정 보완하여 Lee와 Kang (2011)에서 활용한 다문화수용성 5 문항을 합하여 다문화수용성 점수를 산출하였다. 다문화수용성의 구체적인 문항은 (1) 나와 문 화적 배경이 다른 사람을 이웃으로 받아들일 수 있다, (2) 나와 문 화적 배경이 다른 청소년을 같은 반 친구로 받아들일 수 있다, (3) 나와 문화적 배경이 다른 청소년과 가장 친한 단짝이 될 수 있다, (4)이성 친구를 사귀게 된다면, 나와 문화적 배경이 다른 사람을 이 
성친구로 사귈 수 있다, (5) 커서 나와 문화적 배경이 다른 사람과 결 혼할 수 있다, 이다. 응답은 4점 척도로(1점=전혀 그렇지 않다, 2점 $=$ 그렇지 않은 편이다, 3 점 $=$ 그런 편이다, 4 점 $=$ 매우 그렇다) 평정하 였다. 다문화수용성의 Cronbach's $\alpha$ 값은 2차년도(초5) .878, 3차년 도(초6) .873, 4 차년도(중1) .887, 5 차년도(중2) .870로 나타났다.

\section{자아탄력성}

다문화청소년패널 연구에서 조사된 자아탄력성 척도 문항을 활 용하였다. 자아탄력성 척도는 Block과 Kremen (1996)이 개발하고 Yoo와 Shim (2002)이 수정.보완한 것 중 Kim, Baek, Yim과 Lee (2010)에서 발췌하여 사용한 문항들을 활용하였다. 총 14 문항이며 구체적인 측정 문항은 다음과 같다. (1) 내 친구에게 너그럽다, (2) 갑자기 놀라는 일을 당해도 금방 괜찮아지고 그것을 잘 이겨낸다, (3) 평소에 잘 해보지 않았던 새로운 일을 해보는 것을 좋아한다, (4) 사람들에게 좋은 인상을 주는 편이다, (5) 새로운 음식을 먹어보 는 것을 즐긴다, (6) 에너지가 넘치는 사람이다, (7) 같은 장소에 갈 때도 늘 가던 길보다는 다른 길로 가보는 것을 좋아한다, (8) 다른 사람들보다 호기심이 많다, (9) 보통 행동하기 전에 생각을 많이 한 다, (10) 새롭고 다양한 종류의 일하는 것을 좋아한다, (11) 내 생활은 매일 흥미로운 일들로 가득하다, (12) 의지가 강한 사람이라고 자신 있게 말할 수 있다, (13) 다른 사람에게 화가 나도 금방 괜찮아진다, (14) 내가 만나는 대부분의 사람들이 좋다, 이다. 응답은 4점으로( 점 $=$ 전혀 그렇지 않다, 2 점 $=$ 그렇지 않은 편이다, 3 점 =그런 편이다, 4점 $=$ 매우 그렇다) 평정하도록 하였다. 점수가 높을수록 자아탄력 성이 높음을 의미한다. 자아탄력성의 Cronbach's $\alpha$ 값은 2차년도 (초5) .913, 3차년도(초6) .926, 4차년도(중1) .919, 5차년도(중2) .912 로 나타났다.

\section{자료분석 및 결과처리}

두 집단(K only, K-M)의 언어 사용 양상에 따라 자녀의 언어 실 력(한국어, 어머니 모국어), 그리고 국가정체성, 이중문화수용태 도, 다문화수용성, 자아탄력성에서 집단 간 차이가 유의한지 살펴 보기 위해 일원분산분석(one-way ANOVA)를 실시하였으며, 두 집 단(K only, K-M) 각각에서 초등 4 학년 아동의 한국어 및 모국어 능 력은 매개요인(자아탄력성, 국가정체성, 이중문화수용태도, 다문 화수용성)을 통해 중학교 2학년 한국어 및 어머니의 모국어 능력 을 설명하는지 검증하기 위해 구조방정식(Structural equation)을 실시하였다. 매개요인 중, 이중문화수용태도와 다문화수용성 두 변인은 서로 다른 변인인지 확인하고자 요인분석을 실시한 결과, Bartlett의 구형성 검정의 $p<.001$ 으로 나타나 전반적으로 변수 간
상관관계는 유의하며, Kaiser-Meyer-Olkin 역시 .793으로 기준치 .50 보다 높게 나타나 자료가 요인분석에 적합하였다. 또한, 고유값 (eigenvalue)이 1보다 큰 요인이 두 개 추출되었다. 요인 1 (다문화수 용성)의 고유값은 3.037 , 요인 2 (이중문화수용태도)의 고유값은 1.009 이고, 두 요인이 전체 분산의 $50.57 \%$ 를 설명하였다. 본 연구의 통계분석을 위해 일원분산분석은 SPSS ver. 25 , 구조방정식은 AMOS ver. 22 (SPSS Inc, Chicago, IL, USA)를 사용하였다.

\section{연구결과}

\section{두 집단 $(\mathrm{K}, \mathrm{K}-\mathrm{M})$ 간 자녀의 언어 실력의 차이}

한국어

두 집단의 자녀들이 $2,3,4,5$ 차년도에 한국어의 말하기, 듣기, 쓰 기, 읽기 영역의 점수에서 통계적으로 유의한 차이를 보이는지 확 인하기 위하여 일원분산분석을 실시하였다. 그 결과, $2,3,5$ 차년도 의 각 영역에서 통계적으로 유의한 차이를 보이지 않았다( $p>.05)$. 그러나 4 차년도(중 1$)$ 에 한국어만 사용하는 집단 $(\mathrm{M}=3.73, \mathrm{SD}=$ .478)이 한국어와 어머니의 모국어를 혼용하여 사용하는 집단 $(\mathrm{M}=3.60, \mathrm{SD}=.518)$ 에 비해 쓰기 영역의 점수가 유의하게 높았다 $\left(F_{(1,313)}=4.659, p=.032\right)$. 이에 대한 결과를 Figure 1 에 제시하였다.

\section{어머니의 모국어}

두 집단의 자녀들이 $2,3,4,5$ 차년도에 어머니의 모국어의 말하기, 듣기, 쓰기, 읽기 영역의 점수에서 통계적으로 유의한차이를 보이는 지 확인하기 위하여 일원분산분석을 실시하였다. 그 결과, $2,3,4,5$ 차년도의 각 영역에서 한국어와 어머니의 모국어를 혼용하여 사용 하는 집단이 한국어만 사용하는 집단에 비하여 점수가 통계적으로 유의하게 높았다 [2차년도 말하기 $F_{(1,313)}=51.573 ; 2$ 차년도 듣기 $F_{(1,313)}=$ $14.709 ; 2$ 차년도 쓰기 $F_{(1,313)}=27.911 ; 2$ 차년도 읽기 $F_{(1,313)}=72.208$; 3 차년도 말하기 $F_{(1,313)}=88.552 ; 3$ 차년도 듣기 $F_{(1,313)}=29.415 ; 3$ 차년도 쓰기 $F_{(1,313)}=35.159 ; 3$ 차년도 읽기 $F_{(1,313)}=94.755 ; 4$ 차년도 말하기 $F_{(1,313)}=110.256 ; 4$ 차년도 듣기 $F_{(1,313)}=13.586 ; 4$ 차년도 쓰기 $F_{(1,313)}=$ $24.072 ; 4$ 차년도 읽기 $F_{(1,313)}=116.071 ; 5$ 차년도 말하기 $F_{(1,313)}=115.701$; 5 차년도 듣기 $F_{(1,313)}=23.360 ; 5$ 차년도 쓰기 $F_{(1,313)}=32.371 ; 5$ 차년도 읽기 $\left.F_{(1,313)}=129.918,(p<.001)\right]$. 이에 대한 결과를 Figure 2에 제시하였다.

\section{두 집단 $(\mathrm{K}, \mathrm{K}+\mathrm{M})$ 간 자녀의 국가정체성, 이중문화수용태도, 문화수용성, 자아탄력성의 차이 국가정체성}

두 집단의 자녀들이 $2,3,4,5$ 차년도의 국가정체성에 유의한 차이 

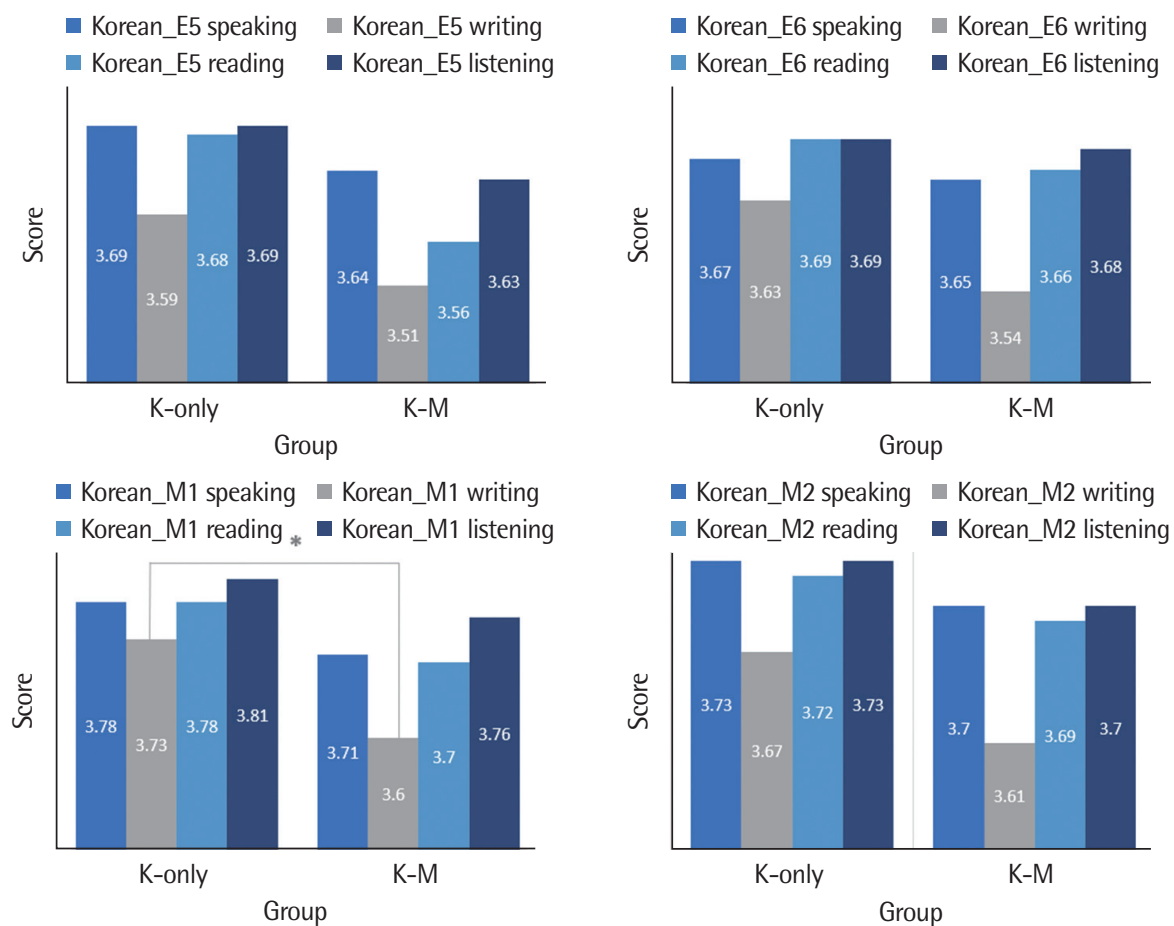

Figure 1. Group differences on Korean abilities. K-only= only Korean speaking group; $\mathrm{K}-\mathrm{M}=$ both Korean and native languages speaking group; $\mathrm{E} 5=5$ th grade in elementary school; $E 6=6$ th grade in elementary school; $M 1=1$ st grade in middle school; $M 2=2 n d$ grade in middle school. ${ }^{*} p<.05$.

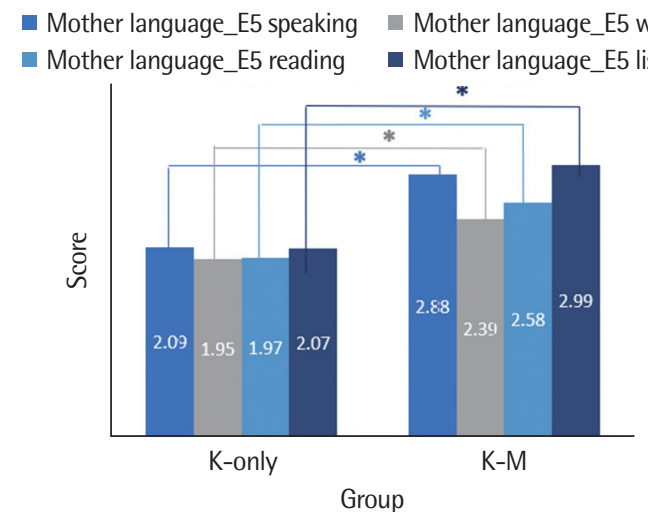

- Mother language_M1 speaking $\quad$ Mother language_M1 writing

- Mother language_M1 reading M Mother language_M1 listening

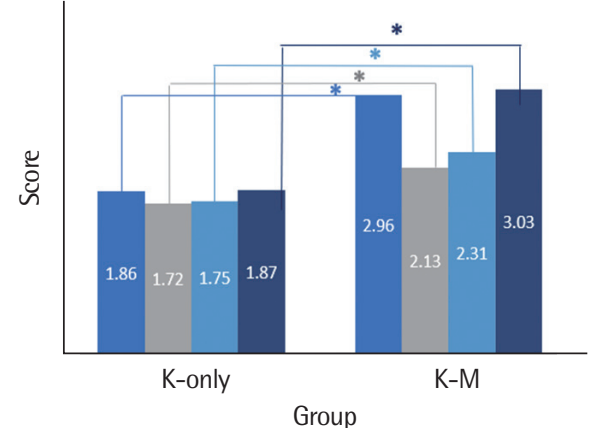

- Mother language_E6 speaking $\quad$ Mother language_E6 writing

- Mother language_E6 reading $\quad$ Mother language_E6 listening

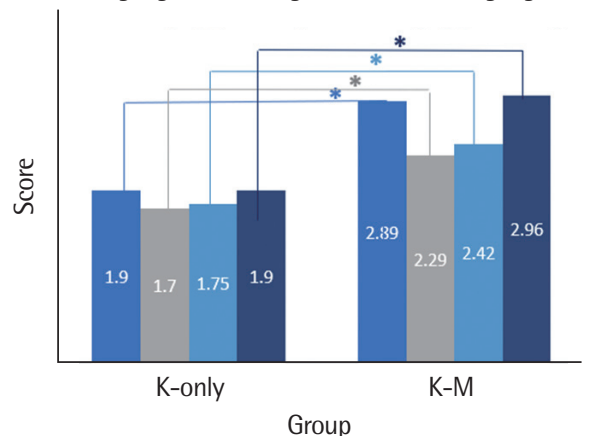

- Mother language_M2 speaking $\quad$ Mother language_M2 writing

- Mother language_M2 reading $\quad$ M Mother language_M2 listening

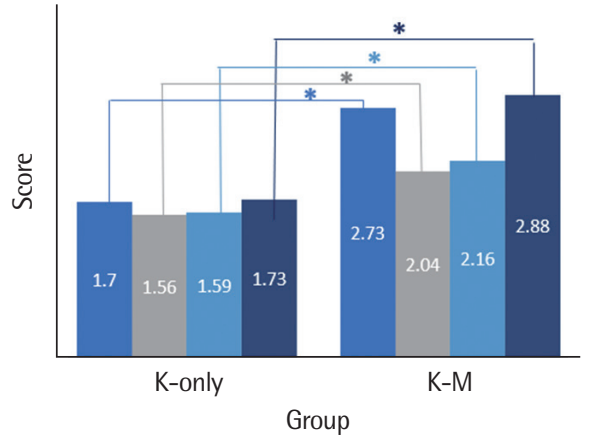

Figure 2. Group differences on mother language abilities. K-only= only Korean speaking group; $K-M=$ both Korean and native languages speaking group; $E 5=5$ th grade in elementary school; $E 6=6$ th grade in elementary school; $M 1$ = 1st grade in middle school; $M 2=2$ nd grade in middle school. ${ }^{*} p<.001$. 
를 보이는지 확인하기 위하여 일원분산분석을 실시하였다. 그 결 과, 국가정체성의 점수는 집단 간 차이가 통계적으로 유의하지 않 았다 $(p>.05)$.

\section{이중문화수용태도}

두 집단의 자녀들이 $2,3,4,5$ 차년도의 이중문화수용태도에 유의 한 차이를 보이는지 확인하기 위하여 일원분산분석을 실시하였다. 그 결과, 한국어와 어머니의 모국어를 혼용하여 사용하는 집단이 한국어만 사용하는 집단에 비해 2차년도(초5)와 3차년도(초6)의 이중문화수용태도 점수가 유의하게 높았다 $\left(F_{(1,313)}=16.545, p=.000\right.$; $\left.F_{(1,313)}=8.174, p=.005\right)$. 이에 대한 결과를 Table 2에 제시하였다.

\section{다문화수용성}

두 집단의 자녀들이 $2,3,4,5$ 차년도의 다문화수용성에 유의한 차이를 보이는지 확인하기 위하여 일원분산분석을 실시하였다. 그 결과 한국어와 어머니 모국어 혼용 집단이 한국어만 사용하는 집

Table 2. Group differences on national identity, bicultural acceptance attitude, acceptance of multiculturalism, and ego-resilience

\begin{tabular}{llll}
\hline Variables & Konly (N=203) & K-M (N=112) & $F$ \\
\hline N & & & \\
E5 & $67.15(15.97)$ & $66.74(15.22)$ & 0.049 \\
E6 & $67.58(16.55)$ & $71.26(14.59)$ & 3.876 \\
M1 & $69.06(16.24)$ & $67.75(16.54)$ & 0.465 \\
M2 & $69.77(17.68)$ & $68.19(15.95)$ & 0.613 \\
B & & & \\
E5 & $70.60(9.66)$ & $75.04(8.53)$ & $16.545^{* * *}$ \\
E6 & $72.34(10.07)$ & $75.71(9.94)$ & $8.174^{* *}$ \\
M1 & $72.96(10.28)$ & $74.69(10.35)$ & 2.038 \\
M2 & $72.09(10.36)$ & $73.86(7.90)$ & 2.468 \\
M & & & \\
E5 & $71.13(14.81)$ & $76.07(15.01)$ & $7.949^{* *}$ \\
E6 & $75.05(13.23)$ & $77.59(14.95)$ & 2.423 \\
M1 & $77.14(14.71)$ & $79.15(13.44)$ & 1.430 \\
M2 & $78.40(13.16)$ & $80.80(12.46)$ & 2.501 \\
R & & & \\
E5 & $72.34(11.93)$ & $76.43(11.85)$ & $8.530^{* *}$ \\
E6 & $74.79(12.87)$ & $78.48(11.38)$ & $6.419^{*}$ \\
M1 & $76.93(12.73)$ & $77.81(10.90)$ & 0.381 \\
M2 & $76.93(12.06)$ & $78.03(10.33)$ & 0.656 \\
\hline
\end{tabular}

Values are presented as mean (SD).

$\mathrm{K}$-only= only Korean speaking group; $\mathrm{K}-\mathrm{M}=$ both Korean and native languages speaking group; $\mathrm{N}=$ national identity; $\mathrm{B}=$ bicultural acceptance attitude; $\mathrm{M}=$ acceptance of multiculturalism; $\mathrm{R}=$ ego-resilience; $\mathrm{E} 5=5$ th grade in elementary school; $\mathrm{E} 6=6$ th grade in elementary school; $\mathrm{M} 1=1$ st grade in middle school; $M 2=2$ nd grade in middle school.

${ }^{*} p<.05,{ }^{* *} p<.01,{ }^{* * *} p<.001$.
단에 비하여 2차년도(초5)에 유의하게 높은 것으로 나타났다 $\left(F_{(1,313)}=7.949, p=.005\right)$. 이에 대한 결과를 Table 2에 제시하였다.

\section{자아탄력성}

두 집단의 자녀들이 $2,3,4,5$ 차년도의 자아탄력성에 유의한 차이 를 보이는지 확인하기 위하여 일원분산분석을 실시하였다. 그 결과, 2차년도(초5)와 3 차년도(초6)에 한국어와 어머니 모국어 혼용 사용 집단이 한국어만 사용하는 집단에 비해 통계적으로 유의하게 높은 것으로 나타났다 $\left(F_{(1,313)}=8.530, p=.004 ; F_{(1,313)}=6.419, p=.012\right)$. 이에 대한 결과를 Table 2에 제시하였다.

\section{두 집단(K, K-M)의 2차년도(초5)와 5차년도(중2) 언어 실력 간 국가정체성, 이중문화수용태도, 다문화수용성, 자아탄력성의 매개효과}

\section{국가정체성}

각 집단의 2 차년도(초5) 언어 실력이 국가정체성을 통해 5 차년도 (중2)의 언어 실력을 설명하는지 알아보기 위하여 구조방정식을 실 시하였다. 매개변인인 국가정체성 점수는 $2,3,4,5$ 차년도(초5, 초6, 중1, 중2) 네 가지를 모두 입력하였다. 그 결과, 두 집단에서 모두 통 계적으로 매개효과가 유의하지 않았다( $p>.05)$.

\section{이중문화수용태도}

각 집단의 2 차년도(초5) 언어 실력이 이중문화수용태도를 통해 5 차년도(중2)의 언어 실력을 설명하는지 알아보기 위하여 구조 방 정식을 실시하였다. 매개변인인 이중문화수용태도 점수는 $2,3,4$, 5 차년도(초5, 초6, 중1, 중2) 네 가지를 모두 입력하였다. 그 결과, 한 국어만 사용하는 집단에서는 매개효과가 유의하지 않았다 $(p>.05)$. 반면, 한국어와 어머니 모국어를 혼용하여 사용하는 집단에서는 2 차년도(초5)의 어머니 모국어 능력이 이중문화수용태도를 매개로 하여 5 차년도(중 2$)$ 의 어머니 모국어 능력을 유의하게 설명하였으며 $\left(\chi^{2}=319.40, p=.000\right), \mathrm{RMSEA}$ 에 의한 적합도는 .092로 기준값인 .05 에 비해 높으나, $\mathrm{CFI}$ 는 .908로 높은 적합도를 보였다. 이에 대한 결과를 Figure 3 에 제시하였다.

\section{다문화수용성}

각 집단의 2 차년도(초5) 언어 실력이 다문화수용성을 통해 5 차 년도(중2)의 언어 실력을 설명하는지 알아보기 위하여 구조방정식 을 실시하였다. 매개변인인 다문화수용성 점수는 $2,3,4,5$ 차년도 (초5, 초6, 중1, 중2) 네 가지를 모두 입력하였다. 그 결과, 한국어만 사용하는 집단과 한국어와 어머니 모국어를 혼용하여 사용하는 


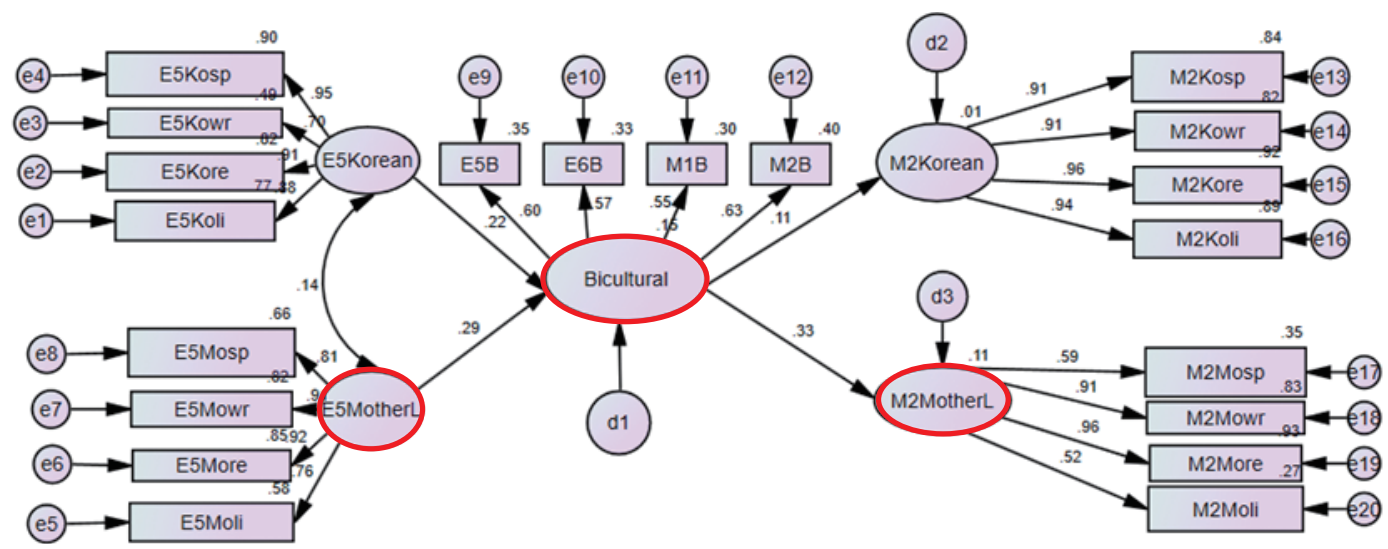

Figure 3. Mediating effects of bicultural acceptance attitude in K-M group.

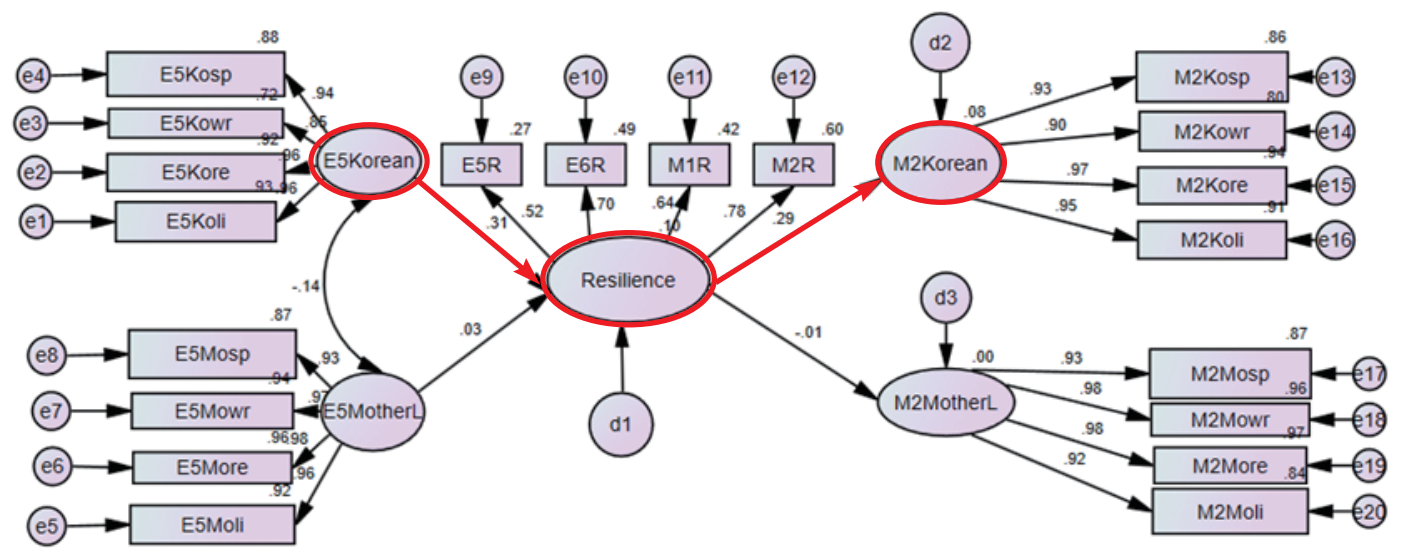

Figure 4. Mediating effects of ego-resilience in K only group.

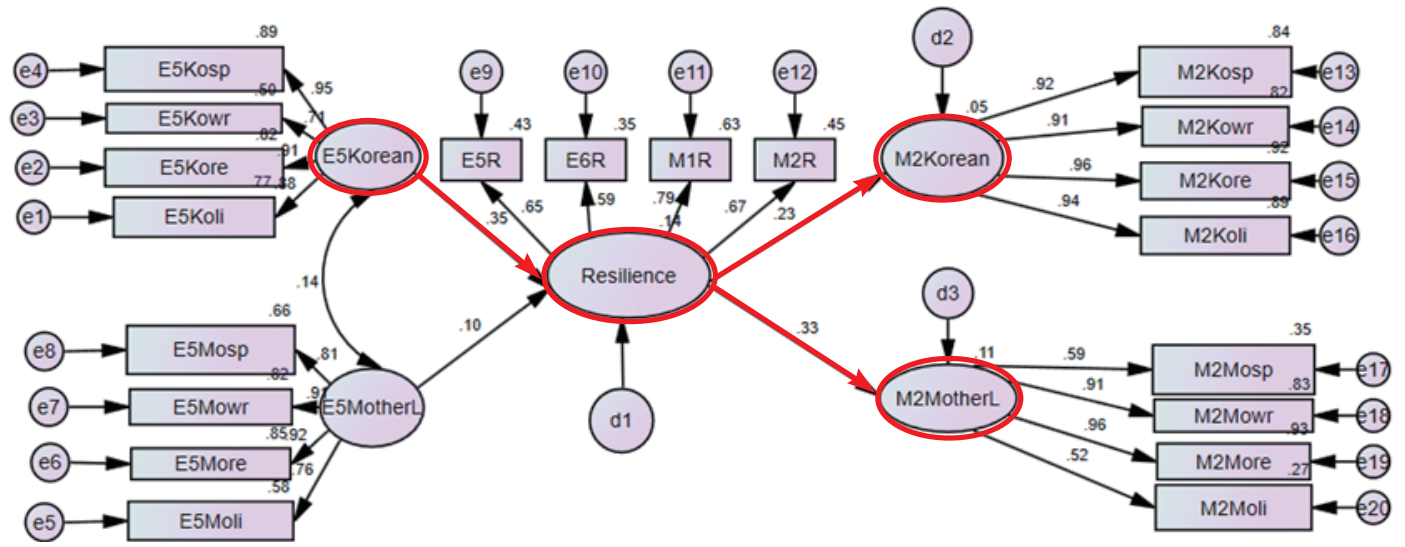

Figure 5. Mediating effects of ego-resilience in K-M group.

집단 모두에서 유의한 매개 효과가 나타나지 않았다 $(p>.05)$.

\section{자아탄력성}

각 집단의 2차년도(초5) 언어 실력이 자아탄력성을 통해 5차년
도(중2)의 언어 실력을 설명하는지 알아보기 위하여 구조방정식을 실시하였다. 매개변인인 자아탄력성 점수는 $2,3,4,5$ 차년도(초 5 , 초 6 , 중 1 , 중2) 네 가지를 모두 입력하였다. 그 결과, 한국어만 사용하 는 집단에서는 2 차년도의 한국어 능력이 자아탄력성을 매개로 하 
여 5 차년도의 한국어 능력을 유의하게 설명하였으며 $\left(\chi^{2}=381.11\right.$, $p=.000)$, RMSEA에 의한 적합도는 .081로 기준값인 .05 에 비해 높 으나, CFI는 .957로 높은 적합도를 보였다. 이에 대한 결과를 Figure 4 에 제시하였다. 또한, 한국어와 어머니 모국어 혼용 집단에서는 2 차년도의 한국어 능력이 자아탄력성을 매개로 하여 5 차년도의 한국어 및 어머니 모국어 능력을 모두 유의하게 설명하였으며 $\left(\chi^{2}=\right.$ $330.51, p=.000), \mathrm{RMSEA}$ 에 의한 적합도는 .095로 기준값인 .05에 비해 높으나, CFI는 .905로 높은 적합도를 보였다. 이에 대한 결과를 Figure 5에 제시하였다.

\section{논의 및 결론}

본 연구에서는 다문화 가정 내 외국인 어머니와 자녀 간 의사소 통 시 사용하는 언어의 양상에 따라 자녀의 언어 실력, 국가정체성, 이중문화수용태도, 다문화수용성, 자아탄력성에 유의한 차이가 있는지 살펴보고자 하였다. 또한 다문화 가정 자녀의 언어 실력을 설명해주는 매개요인으로 국가정체성, 이중문화수용태도, 다문화 수용성, 자아탄력성의 유의한 매개효과를 확인해보고자 하였다. 이를 위해 연구대상을 외국인 어머니와 자녀 간 사용하는 언어에 따라 '한국어만 사용하는 집단'과 '한국어와 어머니의 모국어를 혼용하여 사용하는 집단'으로 나누었다. 또한 각 변수를 종단적으 로 살펴보고자 자녀의 초5-중 2 에 해당하는 2 차-5차년도의 자료를 분석하였다. 본 연구의 결과와 그에 대한 논의는 다음과 같다.

첫째, 두 집단 간 한국어 실력을 비교한 결과 중 1 의 쓰기 영역에 서만 유의한 차이가 나타났고, 그 외의 다른 학년의 전 영역에서는 유의한 차이가 나타나지 않았다. 반면 어머니의 모국어 실력의 경 우 초5-중2의 전 영역(말하기, 듣기, 쓰기, 읽기)에서 한국어와 어머 니의 모국어를 혼용하여 사용한 집단의 점수가 한국어만 사용하 는 집단에 비해 유의하게 더 높았다. 이러한 결과는 어머니의 모국 어와 제 2 언어인 한국어를 함께 사용하는 것이 자녀의 언어 능력에 긍정적인 영향을 미친다는 기존의 선행연구와 일치한다(Park et al., 2014). 두 집단에서 중 1 의 쓰기 영역에 차이가 나타난 것이 중2 때 차이가 사라진 것으로 미루어 보아 학교급간 이동으로 인해 발 생할 수 있는 일시적인 어려움이었던 것으로 보인다. 이러한 흐름은 다문화 학생들의 가정 내 언어 사용 실태에 변화가 필요함을 시사 한다. 즉 가정 내 결혼이민자의 모국어 사용이 장려되고, 다문화 학 생들에게 어머니의 모국어를 가르칠 필요성을 뒷받침한다.

둘째, 두 집단 간의 국가정체성에 유의한 차이가 나타나지 않았 다. 반면 이중문화수용태도, 다문화수용성, 자아탄력성은 어머니 의 모국어와 한국어를 혼용하여 사용하는 집단의 점수가 한국어
만 사용하는 집단에 비해 통계적으로 유의미하게 더 높았다. 세부 적으로는, 이중문화수용태도의 경우 초 5 학년과 6 학년 때, 다문화 수용성은 초 5 학년 때, 자아탄력성은 초 5 학년과 6 학년 때, 어머니 의 모국어와 한국어를 혼용하여 사용하는 집단이 한국어만 사용 하는 집단에 비해 유의하게 더 높았다. 이는 외국인 출신 어머니가 자신의 모국어와 문화를 자녀에게 자연스럽게 노출하였을 때 자녀 가 보다 안정적으로 이중문화정체성을 형성하고 건강한 심리사회 적 발달을 이룬다는 선행연구(Park \& Kim, 2016)를 뒷받침한다. 반 면 국가정체성의 경우, 두 집단 간 유의한 차이를 보이지 않았는데 이는 본 연구 대상의 두 집단 모두 외국인 어머니의 출신 국적을 통 제하지 않아서 집단 내 여러 국적이 혼재하고 집단 간 서로 국적의 비율이 다르기 때문인 것으로 사료된다. 앞서 서론에서 설명한 것 과 같이 다문화 자녀의 국가정체성 형성에는 언어 외에도 다른 요 인이 영향을 미칠 수 있는데 특히 어머니의 출신 국가 및 지역이 이 에 해당하며 동아시아계 어머니 자녀가 비아시아계 어머니 자녀보 다, 그리고 동아시아계 내에서도 조선족 어머니의 자녀가 일본 어머 니의 자녀보다 한국인으로 느끼는 국가정체성이 더 높다고 밝혀졌 다(Geum et al., 2004; Lee \& Kang 2011). 본 연구에서는 연구대상 의 어머니 출신 국가를 특정 국가로 통제하지 않았고 일본, 조선족, 한족을 비롯해 필리핀, 러시아 등 매우 다양하기 때문에 가정 내 어 머니와 자녀가 사용한 언어에 따른 국가정체성의 집단 간 비교가 유의미하게 다르지 않았던 것으로 보인다.

셋째, 한국어만 사용하는 집단과 한국어와 어머니의 모국어를 혼용하여 사용하는 집단에서 초등학교 5 학년의 언어 실력이 매개 요인(국가정체성, 이중문화수용태도, 다문화수용성, 자아탄력성) 을 통해 중학교 2학년의 언어 실력을 설명하는지 살펴본 결과, 국가 정체성의 경우 두 집단 모두에서 매개효과가 유의하지 않았다. 이 는 국가정체성이 매개가 되어 언어의 학습을 촉진시키고 언어 능력 에 영향을 미칠 것이라는 본 연구의 가설과 상반된 결과이다. 서로 다른 민족이 하나의 언어를 사용하며 같은 국가정체성을 형성할 수 있으며(Ormans, 2008), 성장하며 주로 사용하는 언어가 국가정 체성을 내면화하는데 큰 영향을 준다는 선행연구처럼 국가정체성 과 유의한 연관이 있는 것은 사용하는 언어의 종류인 것으로 보인 다(Kim, 2018). 즉, 배우고자 하는 동기나 국가정체성의 정도와 언 어의 상관관계는 낮은 것으로 사료된다. 두 번째 매개변수인 이중 문화수용태도의 경우, 한국어만 사용하는 집단에서는 매개효과가 유의하게 나타나지 않은 반면 한국어와 어머니의 모국어를 혼용하 는 집단에서는 초 5 의 어머니의 모국어 능력이 중 2 의 어머니의 모국 어 능력을 매개하는 효과가 유의하게 나타났다. 이는 가정 내 이중 언어 사용이 자녀의 이중문화수용태도 발달에 긍정적인 영향을 
미쳤으며 모국어 능력을 매개한 것으로 설명할 수 있다. 외국인 어 머니의 모국어에 대한 자연스러운 노출이 외국 문화를 자연스럽게 수용할 수 있도록 하였고, 높은 이중문화수용성이 모국 언어를 사 용하는 능력에도 긍정적인 매개 역할을 하는 것으로 보인다. 한편, 다문화수용성은 두 집단 모두에서 매개효과가 유의하지 않았다. 다문화수용성은 앞서 살펴본 이중문화수용태도와 유사하거나 긴 밀하게 연관된 요소로 간주될 수 있으나, 요인분석 결과 서로 다른 두 변인인 것으로 나타났다. 다양한 문화의 가치를 인정하고 공존 을 수용하는 다문화수용성은 보다 보편적인 가치로 간주될 수 있 는 반면, 이중문화수용태도는 다문화 가정 자녀들에게 한국 내에 서 주류 문화인 한국 문화와 비주류 문화인 외국인 부모 나라의 문 화를 모두 수용하는 태도이므로 보다 직접적으로 자녀들의 언어 능력을 매개할 수 있는 변인으로 나타났을 것으로 추론해볼 수 있 다. 마지막 매개변수인 자아탄력성은 한국어만 사용하는 집단에서 는 초5의 한국어 능력이 중 2 의 한국어 능력을 유의하게 설명하였 으며, 한국어와 어머니 모국어를 혼용하는 집단에서는 초 5 의 한국 어 능력이 중 2 의 한국어 및 어머니 모국어 능력을 모두 유의하게 설 명하였다. 이는 자아탄력성이 언어 능력과 밀접한 관계를 갖는다는 선행연구(Kim \& Yang, 2012)와 일치하며, 다문화 가정의 자아탄력 성이 중요한 보호 요인으로 작용할 수 있음을 시사한다. 본 연구에 서 어머니 모국어와 한국어 혼용 집단의 자아탄력성이 한국어만 사용하는 집단의 자아탄력성보다 높았던 결과를 바탕으로 다문화 가정 내 자녀의 높은 자아탄력성 수준을 위해 외국인 어머니의 모 국어 사용을 적극 장려하는 방향으로 나아가야함을 시사한다. 다 문화 가정 내 외국인 어머니의 모국어 사용은 이처럼 자녀의 언어 발달뿐 아니라 이중문화수용태도, 자아탄력성에 영향을 미칠 수 있다. 따라서 언어 치료 현장에서는 부모 교육을 통하여 외국인 어 머니 모국어 사용의 중요성에 대한 인식을 높이고, 의사소통 시 어 머니가 사용하기에 가장 편안한 모국어를 사용할 수 있도록 지원해 야한다는 임상적 시사점을 가진다.

본 연구의 결과를 바탕으로 다음 사항을 제언하고자 한다. 첫째, 외국인 부모의 언어 사용 양상과 더불어 외국인 부모의 언어 능력 을 고려하여 자녀에게 미치는 영향을 살펴볼 것을 제언한다. 많은 선행연구에서 외국인 출신 부모의 한국어 능력과 다문화 가정 자 녀의 한국어 능력 간의 정적 상관관계를 밝혔을 뿐 아니라(Oh, 2005), 다문화 가정 자녀의 미흡한 한국어 능력의 이유를 외국인 출신 부모의 부족한 한국어 능력에서 찾았다(Oh, Kim, \& Kim, 2009). 따라서 한국어만 사용하는 집단 내에서도 외국인 출신 부모 의 한국어 능력에 따라 서로 다른 결과가 도출될 수 있다. 둘째, 추 후 연구에서는 연구대상을 선정함에 있어 외국인 출신 부모의 국
적을 통제하여 진행할 것을 제언한다. 본 연구에서는 다문화 가정 자녀의 언어에 긍정적인 영향을 미치는 보호 요인을 살펴보고자 하 여 국가정체성이라는 변수 자체가 다문화 가정 자녀에게 미치는 영 향을 거시적으로 살펴보았다. 국가정체성의 경우, 외국인 부모의 출신 국가에 큰 영향을 받을 수 있다(Lee \& Kang, 2011). 따라서 세 부적으로 외국인 부모의 출신 국가에 따라 다르게 형성되는 국가 정체성이 다문화 가정 자녀의 언어 능력에 미치는 영향을 살펴보는 것도 유의미할 것이다.

\section{REFERENCES}

Bennett, M. J., \& Bennett, J. (2004). Developing intercultural sensitivity: an integrative approach to global and domestic diversity. Thousand Oaks, CA: Sage.

Block, J., \& Block, J. H. (1980) The role of ego-control and ego-resiliency in the organization of behavior. In W. A. Collins (Ed), Development of cognition, affect, and social relations: the Minnesota symposia on child psychology (Vol. 13, pp. 33-101). Hillsdale, NJ: Erlbaum.

Block, J., \& Kremen, A. M. (1996). IQ and ego-resiliency: conceptual and empirical connections and separateness. Journal of Personality and Social Psychology, 70(2), 349-361.

Bloom, W. (1990). Personal identity, national identity and international relations. Cambridge: Cambridge University Press.

Cho, Y. D. (2006). The study on the realities of chlid Education in a multicultural family. Seoul: Ministry of Education \& Human Resources Development.

Chung, K. S., \& Lee, S. M. (2011). Special theme: multicultural society and the identity of migrants: Korean national identity from a comparative perspective. Comparative Korean Studies, 19(1), 45-72.

Crystal, D. (2010). The Cambridge encyclopedia of language. Cambridge: Cambridge University Press.

Erikson, E. H. (1959). Identity and the life cycle. New York: W. W. Norton \& Company, Inc.

Erikson, E. H. (1968). Identity: youth and crisis. Toronto: W. W. Norton \& Company, Inc.

Geum, M. J., Kwon, H. S., \& Lee, H. W. (2004). The acculturation process of North Korean adolescent refugees. Journal of Counseling and Psychotherapy, 16(2), 295-308.

Go, E. S., \& Kim, S. H. (2018). The effect of bilingual ability of adolescents in multi-cultural families on school life adaptation: focusing on mediating 
effects of self-esteem and self-resilience. Bilingual Research, 72, 1-23.

Jeong, H. S., Yoo, J. E., \& Lee, J. H. (2007). The understanding of multicultural adolescents. Paju: Yangseowon.

Kim, E. H., CUI LINA, \& Nho, C. R. (2019). Effects of family support on life satisfaction in multicultural adolescents: mediating effects of ego resiliency and school adjustment and multiple group analysis. Journal of Korean Society of Child Welfare, 68, 87-114.

Kim, H. J., \& Lee, T. S. (2015). The effect of students' self-esteem on multicultural acceptability at elementary school level. Journal of Learner-Centered Curriculum and Instruction. 15(2), 479-498.

Kim, J. K., Baek, H. J., Yim, H. J., \& Lee, G. O. (2010). The Annual Report of Korean Children and Youth Panel Survey 2010. Seoul: National Youth Policy Institute.

Kim-Ju, G. M., \& Liem, R. (2003). Ethnic self-awareness as a function of ethnic group status, group composition, and ethnic identity orientation. Cultural Diversity and Ethnic Minority Psychology, 9(3), 289-302.

Kim, K. S. (2011). The relationship between language policy and national identity in Kenya centering on Kiswahili policy. Journal of the Korean Association of African Studies, 33, 3-42.

Kim, M. J. (2018). A study on the national identity of children born in Korean-Japanese multi-cultural families. Journal of Diaspora Studies, 12(1), 307-342.

Kim, M. J., \& Jung, O. B. (2010). Development and validation of a multicultural acceptance inventory for Korean children. The Korean Journal of Human Development, 17(4), 69-88.

Kim, S. K., \& Yang, K. M. (2012). The study on the factors which affect the ego-resiliency of students form multicultural families. Korea Youth Research Association, 19(11), 147-176.

Kim, W. J., Jung, J. A., Shim, T. E., \& Lee, S. Y. (2017). A study of multicultural adolescent changes in resilience by language ability and bicultural acceptance using a latent growth model. Studies on Korean Youth, 28(4), 167-194.

Korean Educational Statistics Service. (2019). The rate of total multicultural students in Korea. Retrieved from https://kess.kedi.re.kr/mobile/stats/scho ol menuCd $=0101 \& \mathrm{~cd}=5034 \&$ survSeq $=2020 \&$ itemCode $=01 \&$ menuId $=\mathrm{m}$ _010105\&uppCd1 $=010105 \& u p p C d 2=010105 \& f l a g=A$.

Lee, H. J., \& Kang, H. A. (2011). A study on the cultural identity, acculturation patterns and psychosocial adjustment of children in international marriage families. Korean Journal of Child Studies, 32(4). 147-166.

Lee, R. H., \& Chang, H. L. (2019). The association between bicultural atti- tude and learning attitude among multicultural adolescents-focusing on the mediated moderation effect of friend support through ego resilience youth facility and environment. Journal of the Korea Institute of Youth Facility and Environment, 17(3), 103-114.

Lim, Y. M. (2019). Relationships between parental support and monitoring and school adjustment in adolescents from multicultural families: mediating role of ego-resilience. Korean Home Economics Education Association, 31(3), 41-55.

Marshall, R. M., \& Neuman, S. (2011). The middle school mind: growing pains in early adolescent brains. Lanham, MD: Rowman \& Littlefield.

Ministry of Gender Equality \& Family. (2018). Status of multicultural family. Retrieved from http://www.mogef.go.kr/as/asl/as_asl_s001.do

Nho, C. R., \& Hong, J. J. (2006). Adaptation of migrant workers' children to Korean society: adaptation of Mongolian migrant worker's children in Seoul, Gyeonggi Area. Journal of the Korean Society of Child Welfare, 22, 127-159.

Oh, S. B. (2005). A case study on the growing of Kosian Children and its social environment. The Journal of Korean Education, 32(3), 61-83.

Oh, S. J., Kim, Y. T., \& Kim, Y. R. (2009). Language characteristics and related family factors in children from multicultural family. Special Education Research, 8(1), 137-161.

Orman, J. (2008). Language policy and nation-building in post-apartheid South Africa. New York: Springer.

Park, A. C. (2002). A study on the relations between identity negotiation process and well-being. The Korean Journal of Educational Psychology, 16(4), 207-228.

Park, H. R., \& Kim, H. C. (2016). The influence of family language of multicultural family on the children's language ability. Korean Journal of Educational Research, 54(4), 165-194.

Park, H. S., Lee, C. W., \& Park, S. E. (2014). Effectiveness of a bilingual and bicultural education program for school-aged children from multicultural families-mediating effects of the process outcomes. Journal of the Korean Society of Child Welfare, 46, 57-83.

Park, Y. H., \& Lee, S. D. (2017). Exploring the predictors of school adjustment and academic achievement during elementary to middle-school transition for adolescents in multicultural families. The Research Institute of Korean Education, 35(4), 1-19.

Seong, H. G. (2001). Development of Korean social identification scale. The Korean Journal of Social and Personality Psychology, 15(3), 33-48.

Sercu, L. (2004). Assessing intercultural competence: a framework for sys- 
tematic test development in foreign language education and beyond. Intercultural education, 15(1), 73-89.

Statistics Korea. (2018). Population and housing census. Retrived from http://kostat.go.kr/assist/synap/preview/skin/doc.html?fn=synapview377115_1\&rs=/ assist/synap/preview.

Wiggins, J. A., Wiggins, B. B., \& Zaden, J. V. (1994). Social psychology (5th ed.). New York: McGraw-Hill.

Yang, G. M., \& Jeong, J. K. (2009). A study on the activation plan for youth multicultural education for social integration. Seoul: National Youth Policy Institute.

Yoo, S. K., \& Shim, H. W. (2002). Pssychological protective factors in resilient adolescents in Korea. The Korean Society of Educational Psychology, 16(4), 189-206.

Yoon, I. J., \& Song, Y, H. (2011). South Korean's perceptions of national identity and acceptance of multiculturalism. The Korean Journal of Unification Affairs, 23(1), 143-192. 


\section{국문초록}

\section{다문화 가정 내 사용 언어에 따른 언어 능력 종단분석: 이중문화수용태도와 자아탄력성의 매개효과 검증 임동선 · 김선영 · 김성진 · 김소은 · 양윤희 \\ 이화여자대학교 언어병리학과}

배경 및 목적: 본 연구는 다문화 가정 내 사용 언어에 따라 한국어만 사용하는 집단과 한국어와 어머니의 모국어를 혼용하는 집단으 로 나누어 자녀의 언어 능력에 차이가 있는지 살펴보았다. 또한 자녀의 초 5 언어 능력이 국가정체성, 다문화수용성, 이중문화수용태도, 자아탄력성을 매개로 중2의 언어 능력을 설명하는지 알아보았다. 방법: 한국청소년정책연구원의 다문화청소년패널조사(MAPS)의 2-5차년도(초5-중2) 학생 및 학부모 데이터를 활용하여 일원분산분석과 구조 방정식을 실시하였다. 결과: 두 집단 간 자녀의 한국어 실 력에 있어 중 1 의 쓰기 능력 외에 유의한 차이가 없었으며 어머니의 모국어 능력은 한국어와 어머니의 모국어 혼용 집단이 매년 유의하 게 높았다. 한국어 사용 집단의 한국어 능력(초5, 중 2 )은 자아탄력성에 의해 매개되었고, 한국어와 어머니의 모국어 혼용 집단의 어머니 의 모국어 능력(초5, 중 2$)$ 은 이중문화수용태도에 의해 매개되었다. 또한, 한국어와 어머니의 모국어 혼용 집단에서는 자아탄력성이 초5 의 한국어 능력과 중 2 의 한국어와 어머니 모국어 능력을 모두 매개하였다. 논의 및 결론: 다문화 가정에서 어머니의 모국어를 혼용하 여 사용하는 것이 자녀의 한국어 능력에 부정적인 영향을 주지 않았다. 이중문화수용태도가 초 5 어머니의 모국어 능력과 중2 어머니 의 모국어 능력을 매개한다는 점과 자아탄력성이 초 5 의 한국어 능력과 중 2 의 한국어 그리고 모국어 능력까지 매개한다는 점에서 이중 언어 환경이 아동의 언어발달에 긍정적이며, 자아탄력성은 다문화 아동의 언어발달을 위한 보호 요인으로 작용할 수 있다.

핵심어: 다문화청소년패널조사(MAPS), 국가정체성, 이중문화수용태도, 다문화수용성, 자아탄력성

본 논문은 2018년 대한민국 교육부와 한국연구재단의 지원을 받아수행된 연구임 (NO. NRF-2018S1A3A2075274).

\section{참고문헌}

교육통계서비스(2019). 다문화학생비율. 진천: 교육통계서비스.

고은선, 김성훈(2018). 다문화가정 청소년의 이중언어능력이 학교생활적응에 미치는 영향 자아존중감과 자아탄력성의 매개효과 중심으로. 이중언

어학, 72, 1-23.

금명자, 권해수, 이희우(2004). 탈북 청소년의 문화 적응 과정 이해. 한국심리학회지: 상담 및 심리치료, 16(2), 195-308.

김광수(2011). 케냐의 언어정책과 국가정체성의 관계. 아프리카학회지, 33, 3-42.

김민지(2018). 한-일 다문화가정 자녀의 국가정체성 연구. 디아스포라연구, 12(1),307-342.

김미진, 정옥분(2010). 아동의 다문화 수용성 척도개발과 타당화 연구. 인간발달연구, 17(4), 69-88.

김승경, 양계민(2012). 다문화가정 학생의 자아탄력성에 영향을 미치는 요인 분석: 이중언어요인, 이중문화요인 및 사회적 지지를 중심으로. 청소년학 연구, 19(11), 147-176.

김은혜, CUI LINA, 노충래(2019). 다문화청소년이 인식한 가족지지가 삶의 만족에 미치는 영향 - 자아탄력성과 학교생활적응 매개효과, 다집단분석. 한국아동복지학, 68, 87-114.

김우진, 정지아, 심태은, 이송이(2017). 잠재성장모형을 활용한 다문화 청소년의 언어능력과 이중문화수용성에 따른 자아탄력성 변화 연구. 한국청소 년연구, 28(4), 167-194.

김현정, 이태상(2015). 초등학생의 자아존중감이 다문화수용성에 미치는 영향 학습자중심교과교육연구, 15(2), 479-498. 김지경, 백혜정, 임희진, 이계오(2010). 한국 아동청소년 패널조사 2010 (연구보고10-R01). 서울: 한국청소년정책연구원. 노충래, 홍진주(2006). 이주노동자 자녀의 한국사회 적응실태 연구. 한국아동복지학, 22, 127-159.

박아청(2002). 정체감 교섭과정과 정신적 건강과의 관련에 관한 연구. 교육심리연구, 16(4), 207-228. 
박용한, 이신동(2017). 다문화가정 청소년의 초-중 전환기 학교적응 및 학업성취 발달 요인에 대한 탐색. 한국교욱문제연구, 35(4), 1-19.

박현선, 이채원, 박소은(2014). 학령기 다문화가정 자녀를 위한 이중언어 · 문화교육의 효과분석-프로그램 과정산물의 매개효과를 중심으로. 한국아

동복지학, 46, 57-83.

박혜랑, 김현철(2016) 다문화가정의 사용언어가 자녀의 언어능력 발달에 미치는 영향. 한국교육학회, 54(4), 165-194.

성한기(2001). 한국판 사회정체화 척도의 개발. 한국심리학회지: 사회 및 성격, 15(3), 33-48.

여성가족부(2018). 다문화 가족 실태 조사. 서울: 여성가족부.

양계민, 정진경(2008). 사회통합을 위한 청소년 다문화교육 활성화방안 연구(연구보고 08-R07). 서울: 한국청소년정책연구원.

오성배(2005). 코시안 아동의 성장과 환경에 관한 사례 연구. 한국교육, 32(3), 61-83.

오소정, 김영태, 김영란(2009). 서울 및 경기지역 다문화가정 아동의 언어특성과 관련변인에 대한 기초 연구. 특수교육, 8(1), 137-161.

유성경, 심혜원(2002). 적응 유연한 청소년들의 심리적 보호요소 탐색. 교육심리학연구, 16(4), 189-206.

윤인진, 송영호(2011). 한국인의 국민정체성에 대한 인식과 다문화수용성. 통일문제연구, 23(1), 143-192.

이래혁, 장혜림(2019). 다문화 청소년의 이중문화수용태도와 학습태도의 관계-자아탄력성을 통한 친구지지의 매개된 조절효과를 중심으로. 청소년

시설환경, 17(3), 103-114.

이현주, 강현아(2011). 국제결혼가정 아동의 문화정체감과 문화적응유형 밀 심리사회적 적응에 관한 연구. 한국아동학회, 32(4), 147-166.

임양미(2019). 부모의 지지 및 감독이 다문화 청소년의 학교생활적응에 미치는 영향: 자아탄력성의 매개효과. 한국가정과교육학회, 31(3), 41-55.

정기선, 이선미(2011). 다문화사회와 이주민의 정체성, 한국인 국민정체성 국제비교연구: 자격요건 평가를 중심으로. 국제비교한국학회, 19(1), 45-73.

정하성, 유진이, 이장현(2007). 다문화청소년이해론. 파주: 양서원.

조영달(2006). 다문화가정의 자녀교육 실태조사. 서울: 교육인적자원부.

통계청(2018). 인구주택총조사. 대전: 통계청.

\section{ORID}

임동선(제1저자, 교신저자, 교수 https://orcid.org/0000-0001-8254-9504); 김선영(공동저자, 대학원생 https://orcid.org/0000-0002-3462-2399); 김성진(공동저자, 대학원생 https://orcid.org/0000-0001-6524-6659); 김소은(공동저자, 대학원생 https://orcid.org/0000-0001-9360-1910);

양윤희(공동저자, 박사후연구원 https://orcid.org/0000-0003-3240-5996) 